\title{
Infection of Curvularia gladioli on different gladiolus genotypes
}

\author{
Denise P. Torres, Mariana A. Silva \& Gleiber Q. Furtado \\ Departamento de Fitopatologia, Universidade Federal de Viçosa, 36570-000, Viçosa, MG, Brazil \\ Author for correspondence: Gleiber Q. Furtado, e-mail: gfurtado@ufv.br
}

\begin{abstract}
In this study the susceptibility of different genotypes of gladiolus (Gladiolus callianthus and the genotypes of G. grandiflorum T-704, Red Beauty, Tradehorn, Verônica, Amsterdam, Yester Gold, and Rose Friendship) was evaluated and correlated with the development of Curvularia gladioli infective structures. The plants were inoculated with a $3 \times 10^{4}$ conidial suspension of the pathogen, and the severity of infection was assessed eight days after inoculation. Leaf samples of G. callianthus and G. grandiflorum vars. Amsterdam, Red Beauty, and T-704 were collected 24 hours after inoculation. They were cleared and the rates of spore germination and appressorium formation of C. gladioli were quantified. G. grandiflorum vars. T-704 and Red Beauty were the most susceptible genotypes, followed by G. callianthus and G. grandiflorum var. Tradehorn. The remaining genotypes did not differentiate among them. No differences related to the conidial germination (93.5\%) were found for the genotypes. However, the highest values for appressorium formation were observed for G. callianthus (66.5\%) and G. grandiflorus var. Amsterdam (55.7\%), and the lowest values were observed for T-704 (32.4\%). Thus, appressorium formation of $C$. gladioli was higher on leaf surfaces of resistant genotypes.
\end{abstract}

Key words: Gladiolus callianthus, Gladiolus grandiflorum, appressorium, curvularia leaf spot, flower bulb.

Gladiolus is an ornamental plant of high economic value and occupies a prominent position in the global flower bulb industry (Benschop et al., 2010). Gladiolus is part of the Iridaceae family, together with Iris and Crocus (Meerow, 2012), and includes more than 260 species originating from Africa, Madagascar and Eurasia (Goldblatt et al., 2008). Gladiolus flowers of various colors are currently commercially available, and white and red flowers are preferred by Brazilian consumers (Tombolato et al., 2010).

It is estimated that $60 \%$ of gladiolus corms in Brazil are intended for the production of cut flowers for the domestic market and the remaining $40 \%$ are exported, especially to Holland (Tombolato et al., 2010).

There are several pathogens, such as Botrytis gladiolorum Timmerm, Curvularia spp., Fusarium oxysporum f. sp. gladioli (Massey) W.C. Snyder \& H.N. Hansen, Fusarium solani (Mart.) Sacc. Geotrichum candidum Link, Septoria gladioli Pass., Phyllosticta gladioloides Bat., Stemphylium sp. and Uromyces transversalis (Thüm.) G. Winter, that infect gladiolus and cause reduction in the yield and quality of the flowers and corms, as well as increasing the cost of production (Magie, 1953; Baiswar et al., 2007; Shakir et al., 2008; Tombolato et al., 2010). The first report of Curvularia in gladiolus was in Florida in 1947 (Magie, 1948). Since then, it has quickly become globally distributed (Boerema \& Hamers, 1989). In Brazil, the curvularia leaf spot caused by $C$. gladioli Boerema \& Hamers has recently been reported in $G$. grandiflorum vars. T-704 and Amsterdam. The symptomatic tissues showed leaf spots that were oval to circular, brown with dark edges, and surrounded by a yellow halo (Torres et al., 2013).

Gladiolus breeding programs attempt to improve gladiolus features such as the color, number and shape of flowers, flowering capacity in winter, multiplication and resistance to foliar and corm diseases (Magie, 1960; Cantor, 2006). In Brazil, in addition to agronomic characteristics such as productivity and adaptability, breeding programs are focused on the search for genotypes that are resistant or tolerant to rust ( $U$. transversalis), which is the most significant disease of gladiolus in this country (Tombolato et al., 2010).

Despite the importance of curvularia leaf spot, there is no information available concerning the reaction of gladiolus genotypes to $C$. gladioli. Therefore, we evaluated the susceptibility of different species and varieties of gladiolus grown in Brazil to curvularia leaf spot caused by $C$. gladioli and correlated it with the development of infective structures of the pathogen.

The genotypes tested were: Gladiolus callianthus Mosais and the varieties of Gladiolus grandiflorum L. T-704, Red Beauty, Tradehorn, Verônica, Amsterdam, Yester Gold, and Rose Friendship. The C. gladioli isolate CMM 4055 (Torres et al., 2013) was used to inoculate the gladiolus plants. The isolate was grown in Petri dishes on corn-carrot agar at $25^{\circ} \mathrm{C}$ in the dark to induce sporulation. After 21 days, $10 \mathrm{~mL}$ of distilled water was added to each Petri dish, the fungal colonies were removed with a glass 
rod, and the suspension was filtered through one layer of cheesecloth. The conidial concentration was adjusted to 3 x $10^{4}$ conidia $\mathrm{mL}^{-1}$.

The conidial suspension was sprayed on the lower surface of gladiolus leaves until the maximum number of drops was retained. Twenty-one-day-old G. callianthus and G. grandiflorus vars. Amsterdam, Red Beauty, Friendship Rose, T-704, Tradehorn, Verônica, and Yester Gold were used. The inoculated plants were moistened, wrapped in plastic bags to maintain a saturated environment, and kept in a growth chamber at $25^{\circ} \mathrm{C}$ with a photoperiod of $12 \mathrm{~h}$ of light for $30 \mathrm{~h}$. The plastic bags were removed, and the plants were transferred to a growth chamber at $22^{\circ} \mathrm{C}$ with a photoperiod of $12 \mathrm{~h}$ of light.

The assessment of the severity of the curvularia spot was performed eight days after inoculation. Leaf sections of $17 \mathrm{~cm}$, from the edge of the leaf, were scanned, and the images were analyzed for the proportion of healthy and diseased tissue using the QUANT software v. 1.01 (Universidade Federal de Viçosa, 2003).

The experiment used a completely randomized design with four replicates, and each replicate consisted of two leaves, one fully expanded leaf and one young leaf, per plant. The experiment was repeated once. Data were analyzed by analysis of variance, using the arcsine root transformation of the proportion of the severity. The means were compared by Tukey test at $5 \%$ probability using SAS software Version 9.0 (SAS Institute). The results of the two trials were pooled because homogeneity of variance was confirmed by Bartlett's test (Gomes \& Garcia, 2002).

The percentages of conidial germination and appressorium formation were evaluated in G. callianthus and G. grandiflorus vars. Amsterdam, Red Beauty and T-704. Twenty leaf samples of approximately $1 \mathrm{~cm}^{2}$ were randomly collected from each treatment $24 \mathrm{~h}$ after inoculation and transferred to glass vials containing a $1 \mathrm{~g} \mathrm{~mL}^{-1}$ solution of chloral hydrate (Vetec). The leaf samples were stained with lacto-fuchsin $(0.1 \%)$, transferred to glass slides containing a drop of glycerinated water $(50 / 50 \mathrm{v} / \mathrm{v})$ and observed with a light microscope. The data were analyzed by analysis of variance, and the means were compared using the Duncan test at $5 \%$ probability. The relationship between the percentages of appressorium formation and the severity of curvularia leaf spot was assessed by Pearson's correlation using SAS software v. 9.0.

The genotypes showed different levels of susceptibility to $C$. gladioli (Table 1). G. grandiflorus vars. T-704 and Red Beauty were the most susceptible, followed by G. callianthus and G. grandiflorus var. Tradehorn. The G. grandiflorus vars. Amsterdam, Rose Friendship, Verônica, Tradehorn and Yester Gold varieties were the most resistant, and there were no significant differences among them. There are several varieties of gladiolus that are highly resistant to leaf spot caused by C. gladioli (Magie, 1953). The susceptibility of 46 varieties of gladiolus to Fusarium rot and leaf spots caused by Botrytis and Curvularia were
TABLE 1 - Severity of curvularia leaf spot in Gladiolus callianthus and seven varieties of Gladiolus grandiflorus incubated in a climatic chamber at $22^{\circ} \mathrm{C}$ eight days after inoculation with Curvularia gladioli

\begin{tabular}{lrl}
\hline \hline Genotypes & Severity (\%) \\
\hline Gladiolus grandiflorus var. T-704 & 21,46 A \\
G. grandiflorus var. Red Beauty & $11,92 \quad \mathrm{~B}$ \\
Gladiolus callianthus & $5,20 \mathrm{C}$ \\
G. grandiflorus var. Tradehorn & $1,96 \mathrm{CD}$ \\
G. grandiflorus var. Verônica & $1,15 \mathrm{D}$ \\
G. grandiflorus var. Amsterdam & $0,68 \mathrm{D}$ \\
G.grandiflorus var. Yester Gold & $0,34 \mathrm{D}$ \\
G. grandiflorus var. Rose Friendship & $0,05 \mathrm{D}$ \\
\hline
\end{tabular}

Means followed by the same letters in the column do not differ by Tukey test at $5 \%$ probability. The data were transformed to arcsine root of the proportion of severity.

evaluated by McClellan \& Pryor (1957), who found that, on a scale of 0 to 4 , only four varieties showed a severity of curvularia leaf spot less than or equal to one, and ten were very susceptible to disease. However, the conditions in which plants were incubated after inoculation were different from those used in this work. McClellan \& Pryor (1957) kept the gladiolus at $29^{\circ} \mathrm{C}$ for $48 \mathrm{~h}$ and subsequently transferred them to a greenhouse until evaluation of disease symptoms.

On fully expanded leaves, the first lesions were observed between 3 and 4 days after inoculation. There were differential responses among the genotypes. The most susceptible varieties showed circular to oval leaf spots, which were gray to dark brown with or without a yellow halo. The spots became irregular in shape and extended along the vein of the leaf. In G. grandiflorus var. T-704, the spots became necrotic, and the leaves acquired a wilted aspect (dry). In G. grandiflorus var. Red Beauty, the spots also became necrotic; however, the spots were always surrounded by yellow halos. The spots in G. callianthus were round and always surrounded by yellow halos. In the less susceptible genotypes, G. grandiflorus varieties Amsterdam, Friendship Rose, Tradehorn, Veronica and Gold Yester, small, light brown to dark brown spots were observed.

McClellan \& Marshall (1950) reported that $C$. gladioli infects the Picardy variety in a temperature range from $7^{\circ} \mathrm{C}$ to $30^{\circ} \mathrm{C}$, with the optimal temperature between $24^{\circ} \mathrm{C}$ and $30^{\circ} \mathrm{C}$. Jackson (1961) reported that infection of the leaves of the Corona, Florida Pink and Valeria varieties occurred from $24^{\circ} \mathrm{C}$ to $36^{\circ} \mathrm{C}$. In this study, leaf infection occurred in all varieties tested at $22^{\circ} \mathrm{C}$; however, there was no sporulation of the pathogen. Lack of sporulation was most likely due to the lower temperature used in this experiment.

Conidia showed polar germination (Figure 1A), frequently occurring at both ends simultaneously. The germ tubes grew in random directions, and sometimes ramifications 


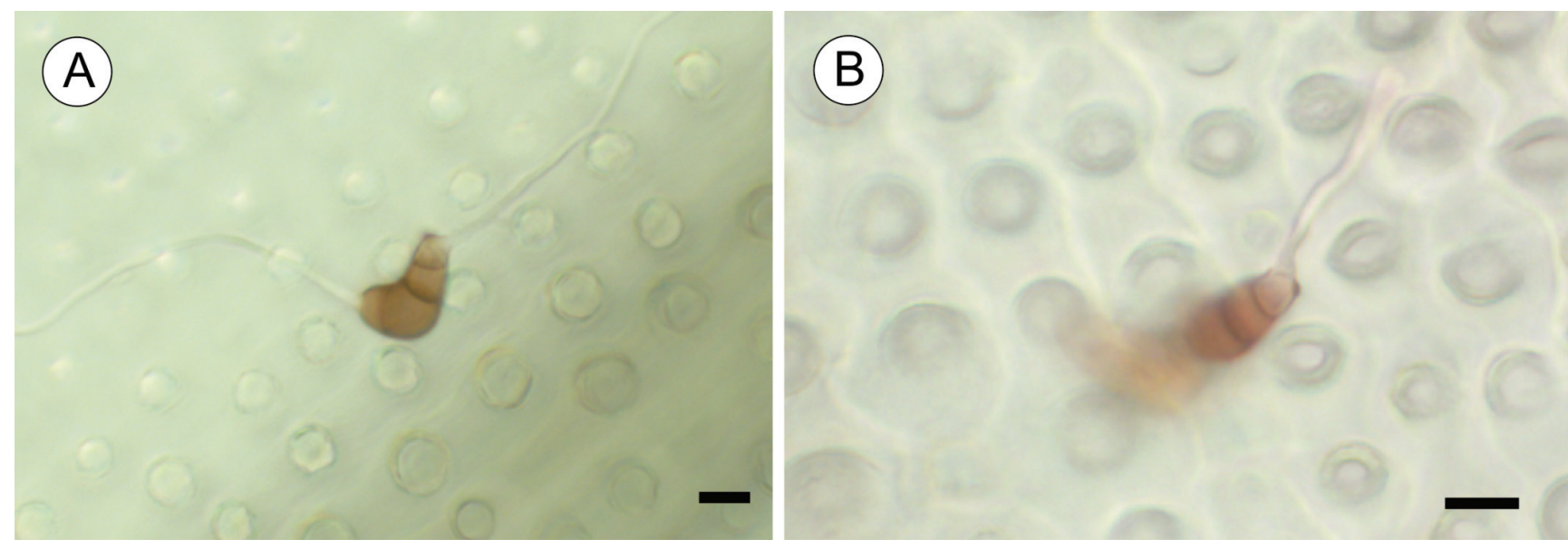

FIGURE 1 - Germination of conidia of Curvularia gladioli inoculated on the abaxial surface of Gladiolus grandiflorus vars. Amsterdam (A) and Read Beauty (B) at $25^{\circ} \mathrm{C} 24 \mathrm{~h}$ after inoculation. A. Bipolar germination; B. Unipolar germination with formation of hyaline appressoria on epidermal cells. Bars $=10 \mathrm{~mm}$.

were observed. The majority of conidia (93.5\%) germinated $24 \mathrm{~h}$ after inoculation, but this did not differ between the genotypes. Therefore, there was no relationship between susceptibility to curvularia leaf spot and the percentage of spore germination. Similar results were observed in rice (Curvularia tuberculata B.L. Jain and C. oryzae Bugnic.); corn (Exserohilum turcicum (Pass.) K.J. Leonard \& Suggs); and apple (Colletotrichum gloeosporioides (Penz.) Penz. \& Sacc.) (De Luna et al., 2002; Muiru et al., 2008; Araújo \& Stadnik, 2011). Magnani et al. (2007) reported that in leaves of different soybean cultivars inoculated with Phakopsora pachyrhizi Syd. \& P. Syd., the germination of conidia on the surface of susceptible genotypes was higher than that on the surface of resistant genotypes and that the resistance of the genetic material tested was observed in the pre-penetration phase.

Hyaline appressoria (Figure 1B) formed mainly in the epidermal cells, but some formed on stoma. The percentages of appressorium formation differed between the genotypes. The highest values were observed in G. callianthus $(66.5 \%)$ and G. grandiflorus var. Amsterdam (55.7\%) and the lowest values were observed in G. grandiflorus var. T-704 (32.4\%) (Figure 2). Thus, we observed a negative correlation $(r=-0.64)$ between the severity of curvularia leaf spot and the percentage of appressorium formation. In most pathosystems, the early events of pathogen infection, conidial germination and appressorium formation are similar on susceptible and resistant surfaces (Bell, 1981). However, a direct relationship between the percentage of appressorium formation and the susceptibility to pathogen has been found in guarana (Colletotrichum guaranicola F.C. Albuq.); tomato (Alternaria solani Sorauer); and soybean (P. pachyrhizi) (Bentes \& Matsuoka, 2002; Araujo \& Matsuoka, 2004; Magnani et al., 2007). The results of this study indicate that different genotypes of gladiolus grown

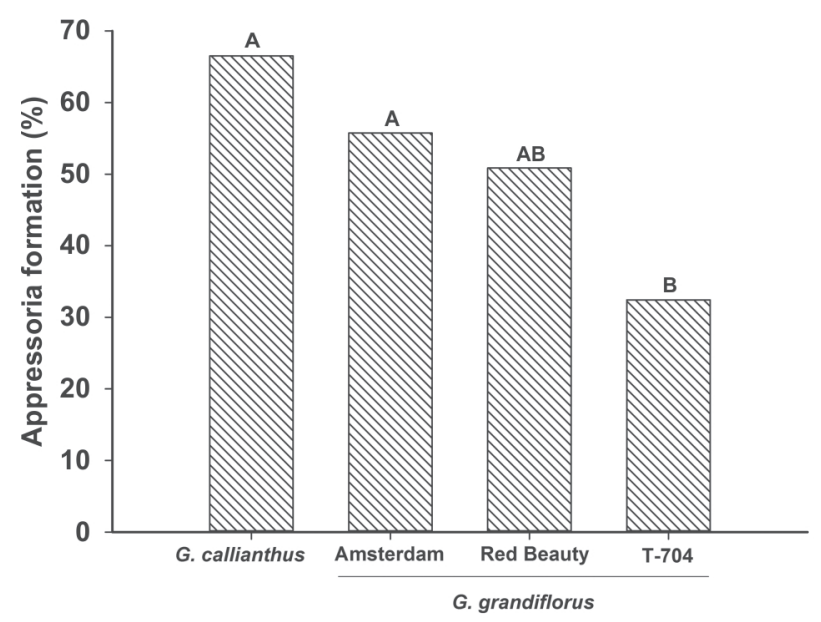

FIGURE 2 - Percentages of appressorium formation of Curvularia gladioli inoculated on the lower surface of leaves of Gladiolus calliantus and Gladiolus grandiflorus vars. Amsterdam, Red Beauty and T-704 $24 \mathrm{~h}$ after inoculation. Columns followed by the same letter do not differ by the Duncan test at $5 \%$ probability.

in Brazil have different reactions to curvularia leaf spot. G. grandiflorus var. T-704 is the most susceptible, and $G$. grandiflorus vars. Amsterdam, Friendship Rose, Veronica, Tradehorn and Gold Yester are the least susceptible. Resistance to this disease is not related to the percentage of conidial germination; however, it is positively correlated with the percentage of appressorium formation.

Considering the high susceptibility of some species and varieties of Gladiolus to curvularia leaf spot, further studies encompassing a larger number of varieties and isolates of this pathogen must be performed to detect sources of resistance to C. gladioli in this ornamental. 


\section{ACKNOWLEDGEMENTS}

The authors thank Fundação de Amparo à Pesquisa do Estado de Minas Gerais - FAPEMIG, Conselho Nacional de Desenvolvimento Científico e Tecnológico - CNPq and Coordenação de Aperfeiçoamento de Pessoal de Nível Superior - CAPES for financial support.

\section{REFERENCES}

Araujo JCA, Matsuoka K (2004) Histopatologia da interação Alternaria solani e tomateiros resistente e suscetível. Fitopatologia Brasileira 29:268-275.

Araújo L, Stadnik MJ (2011) Processo infeccioso e atividade de enzimas em plântulas de macieira de genótipo resistente ou suscetível à mancha foliar de glomerella causada por Colletotrichum gloeosporioides. Tropical Plant Pathology 36:241-248.

Baiswar P, Chandra S, Kumar R (2007) Status of gladiolus diseases and their management in India - A review. Journal of Ornamental Horticulture 10:209-214.

Bell AA (1981) Biochemical mechanisms of disease resistance. Annual Review of Plant Physiology 32:21-81.

Benschop M, Kamenetsky R, Le Nard M, Okubo H, De Hertogh A (2010) The global flower bulb industry: Production, utilization, research. Horticultural Reviews 36:1-115.

Bentes JLS, Matsuoka K (2002) Histologia da interação Colletotrichum guaranicola e Paullinia cupana var. sorbilis em clones resistente e suscetível. Fitopatologia Brasileira 27:71-77.

Boerema GH, Hamers MEC (1989) Check-list for scientific names of common parasitic fungi. Series $3 \mathrm{~b}$ : Fungi on bulbs: Amaryllidaceae and Iridaceae. Netherlands Journal of Plant Pathology 95:1-32.

Cantor M (2006) Genetic breeding of Gladiolus hybridus in Romania. HortScience 41:1041.

De Luna LZ, Watson AK, Paulitz TC (2002) Reaction of rice (Oryza sativa) cultivars to penetration and infection by Curvularia tuberculata and C. oryzae. Plant Disease 86:470-476.

Goldblatt P, Rodriguez A, Powell MP, Davies TJ, Manning JC, Van der Bank M, Savolainen V (2008) Iridaceae "Out of Australasia"? Phylogeny, biogeography, and divergence time based on plastid
DNA sequences. Systematic Botany 33:495-508.

Gomes FP, Garcia CH (2002) Estatística aplicada a experimentos agronômicos e florestais. Piracicaba SP, Brazil. FEALQ.

Jackson CR (1961) Some host-parasite relationships in the curvularia disease of gladiolus in Florida. Plant Disease Reporter 45:512-516.

Magie RO (1953) Some fungi that attack gladiolus. Yearbook of Agriculture. Washington DC, USA. USDA.

Magie RO (1960) Breeding gladiolus for Florida. Proceedings of the Florida State Horticultural Society 72:375-378.

Magie RO (1948) Curvularia spot, a new disease of gladiolus. Plant Disease Reporter 32:11-13.

Magnani EBZ, Alves E, Araújo DV (2007) Eventos dos processos de pre-penetração, penetração e colonização de Phakopsora pachyrhizi em folíolos de soja. Fitopatologia Brasileira 31:156160.

McClellan WD, Marshall BH (1950) Effect of temperature on the development of some diseases of Gladiolus, Narcissus and Lilium. Phytopathology 40:872.

McClellan WD, Pryor RL (1957) Susceptibility of gladiolus varieties to Fusarium, Botrytis and Curvularia. Plant Disease Reporter 41:47-50.

Meerow AW (2012) Taxonomy and phylogeny. In: Kamenetsky R, Okubo H (Eds.) Ornamental geophytes: From basic science to sustainable production. Boca Raton FL, USA. CRC Press. pp. 1756.

Muiru WM, Mutitu EW, Kimenju JW, Koopmann B, Tiedemann AV (2008) Infectious structures and response of maize plants to invasion by Exserohilum turcicum in compatible and incompatible host pathogen systems. Journal of Applied Biosciences 10:532537.

Shakir AS, Haq E, Ayub M (1998) Studies on pathogenicity and eradication of some fungal disease of gladiolus in Pakistan. Pakistan Journal of Biological Sciences 1:23-26.

Tombolato AFC, Uzzo RP, Junqueira AH, Peetz MS, Stancato GC, Alexandre MAV (2010) Bulbosas ornamentais no Brasil. Revista Brasileira de Horticultura Ornamental 16:127-138.

Torres DP, Silva MA, Pinho DB, Pereira OL, Furtado GQ (2013) First report of Curvularia gladioli causing a leaf spot on Gladiolus grandiflorus in Brazil. Plant Disease 97:847. 